mary leiomyosarcoma of the truncus pulmonalis. Path Res Pract 1990;186:296-9.

10. Berney CR, Roche B, Kurt AM, Spiliopoulos A, Megevand $\mathrm{R}$. Leiomyosarcoma of the pulmonary hilar vessels. Thorac Cardiovasc Surg 1992;40:48-51.

11. Johansson L, Carlen B. Sarcoma of the pulmonary artery: report of four cases with electron microscopic and immunhistochemical examinations, and review of the literature. Virchows Arch 1994;424:217-24.

12. Kawamura M, Takahasi Y, Sakata $Y$, et al. A case of malignant fibrous histiocytoma of the pulmonary artery. Nippon Kyobu Geka Gakkai Zasshi 1994;42:456-60.

\title{
SALVAGE RESECTION OF A CHEMOREFRACTORY MEDIASTINAL GERM CELL TUMOR
}

Michel Rivoire, MD, PhD, ${ }^{a}$ Eric Voiglio, MD, ${ }^{a}$ Pierre Kaemmerlen, MD, ${ }^{b}$ Isabelle Treilleux, MD, ${ }^{c}$ Pierre Biron, MD, ${ }^{d}$ and Jean Pierre Droz, MD, ${ }^{\mathrm{d}}$ Lyon, France

Primary mediastinal nonseminomatous germ cell tumors are uncommon, accounting for only $1 \%$ to $3.5 \%$ of all tumors of the mediastinum and $1 \%$ to $2 \%$ of all germ cell tumors in male patients. ${ }^{1}$ Outcome for these tumors has improved considerably with the combination of cisplatin-based chemotherapy followed by aggressive operation. $^{2}$ Nevertheless, $50 \%$ to $60 \%$ of cases are not cured by this multimodal approach; almost all patients who have only partial response status without return to normal serum levels of tumor marker and those who have relapses

From the Departments of Surgery, ${ }^{\mathrm{a}}$ Radiology, ${ }^{\mathrm{b}}$ Pathology, ${ }^{\mathrm{c}}$ and Medecine, ${ }^{\mathrm{d}}$ Léon Bérard Cancer Center, Lyon, France.

Received for publication March 19, 1996; accepted for publication March 26, 1996.

J Thorac Cardiovasc Surg 1996;112:1124-6

Copyright (C) 1996 by Mosby-Year Book, Inc.

$0022-5223 / 96 \$ 5.00+0 \quad \mathbf{1 2 / 5 4 / 7 3 7 8 7}$ with elevated levels of tumor marker die, even when treated with high-dose chemotherapy and hematopoietic stem-cell support. Salvage resection of chemorefractory germ cell tumors of the testis was recently reported to result in a cure rate of $50 \%$ in one patient population. ${ }^{3}$ Salvage resection of mediastinal germ cell tumors has not yet been reported. We describe the case of a patient with a chemorefractory primary mediastinal germ cell tumor in whom a series of operations resulted in sustained, complete remission.

A 30-year-old man was referred to our hospital in February 1992 for a histologically confirmed pure primary choriocarcinoma of the anterosuperior mediastinum with widespread lung metastases (Fig. 1). Ultrasonography showed both testes to be normal. No other metastatic sites were detected with whole-body computed tomographic scan. The initial serum level of human chorionic gonadotrophin hormone (hCG) was $80,000 \mathrm{mIU} / \mathrm{ml}$ (normal $<4$

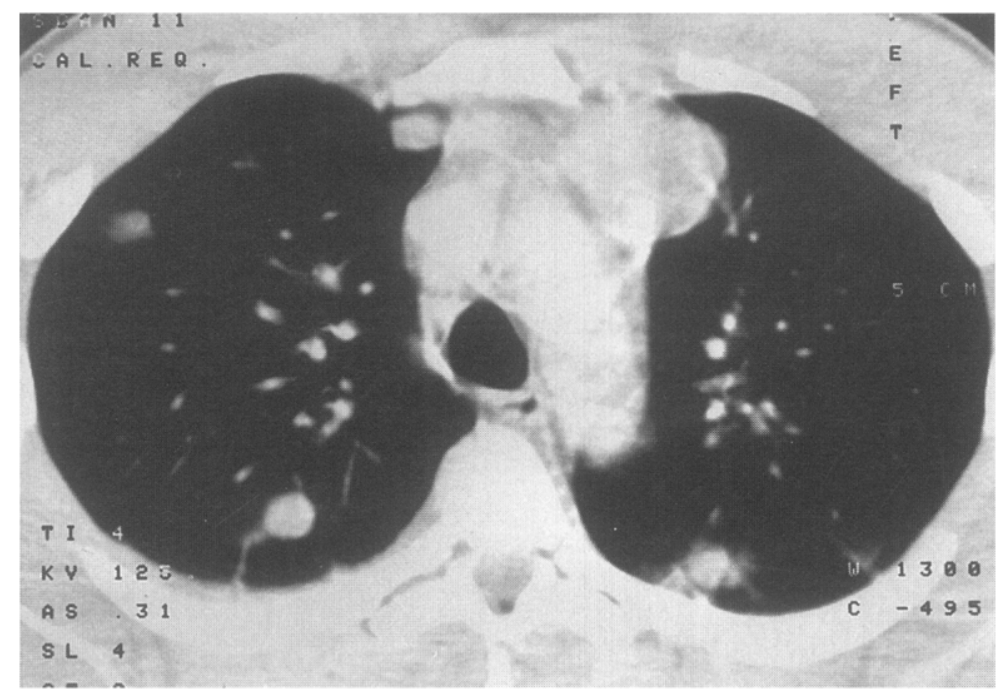

Fig. 1. Chest computed tomographic scan showing tumor of anterosuperior mediastinum with bilateral lung metastases. 


\section{Surgical procedures}

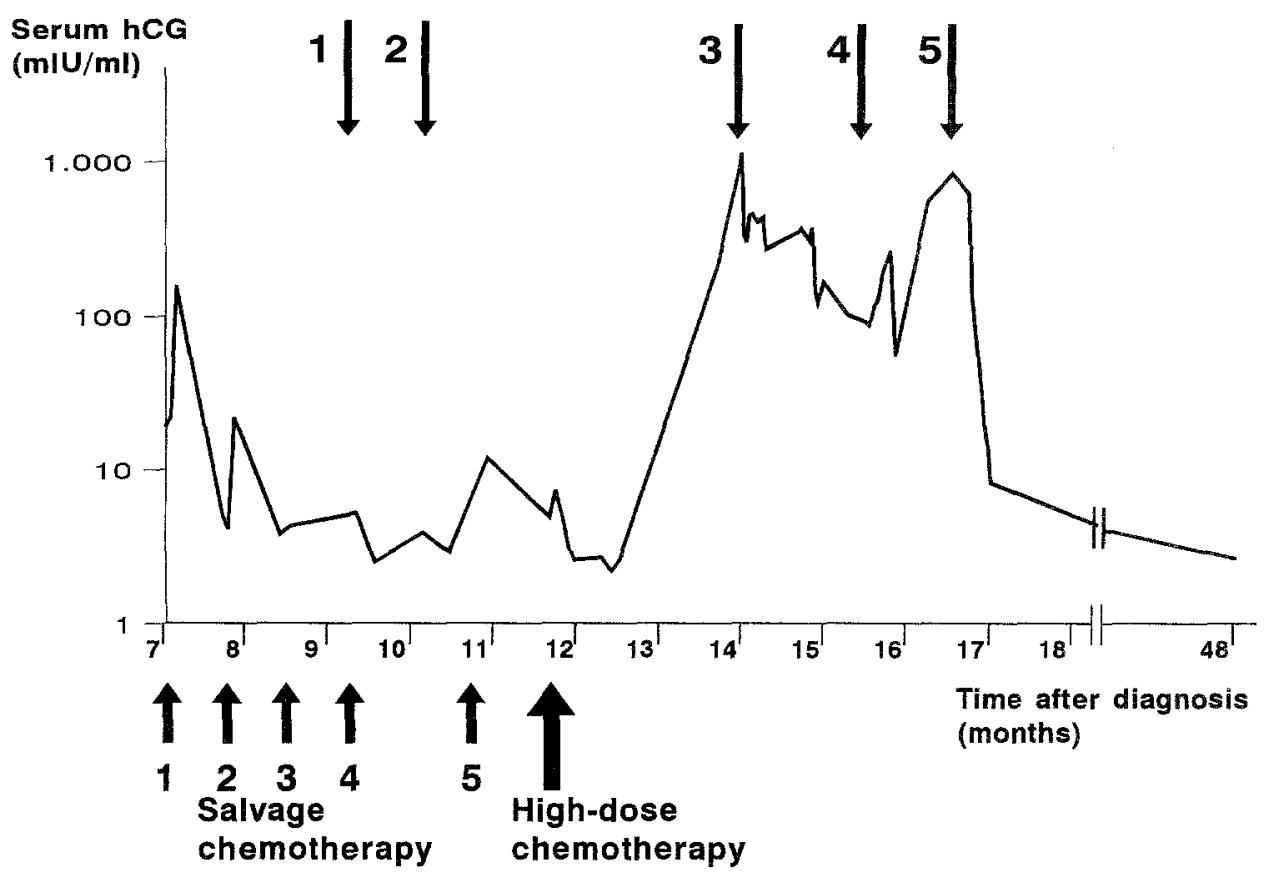

Fig. 2. Changes in serum hCG levels with time (semilogarithmic scale). Initial phase of treatment is not shown.

$\mathrm{mIU} / \mathrm{ml}$ ), and that of $\alpha$-fetoprotein was $2.3 \mathrm{ng} / \mathrm{ml}$ (normal $<10 \mathrm{ng} / \mathrm{ml}$ ). The patient received four cycles of a standard bleomycin, etoposide, and cisplatin chemotherapeutic regimen. There was a partial response, but the serum hCG level remained elevated. The patient was switched to a salvage chemotherapeutic regimen of vinorelbine, ifosfamide, and epirubicin; his serum hCG level returned to normal after four cycles of this regimen. All residual diseased tissue was resected in a two-stage operation: median sternotomy with resection of the tumor of the anterosuperior mediastinum and wedge resection of 14 nodules of the left lung (procedure 1, Fig. 2) and wedge resection of 11 nodules of the right lung 1 month later (procedure 2). All but one of the tumor sites were found to be necrotic on histologic examination. A residual active choriocarcinoma pattern was found in one nodule in the right lung. In February 1993, the patient received one cycle of high-dose consolidation chemotherapy with etoposide, ifosfamide and double-dose cisplatin and also received bone-marrow support. By April 1993, the patient's serum hCG level had increased to $1142 \mathrm{mIU} / \mathrm{ml}$. At that time two new nodules were found in the right lung by chest computed tomographic scan and resected with a wedge technique (procedure 3). Histologic examination showed fibrosis. The serum hCG level declined for less than 1 month but then increased rapidly, and a new nodule appeared in each lung. Wedge resection of the nodule in the left lung (procedure 4), which was fibrotic, failed to lower the serum hGC level; resection of the nodule in the right lung (procedure 5), however, revealed the presence of histologic active choriocarcinoma. After resection of the nodule in the right lung, the patient's serum hCG level again decreased to normal. The patient was closely followed up from July 1993 to February 1996 and is alive and free of disease.

Although they share many histologic and serologic features with testicular germ cell tumors, primary mediastinal nonseminomatous germ cell tumors represent a clinically and cytologically distinct entitity. Differences in mediastinal primary tumors ${ }^{3}$ include a relationship with Klinefelter's syndrome, occurrence of hematologic malignancies, and a poorer prognosis with conventional cisplatin-based combination chemotherapy.

Patients receive aggressive treatment with cisplatinbased combination chemotherapy and surgical excision of residual disease can expect a $50 \%$ cure rate. ${ }^{1}$ Unfortunately, the outlook for those patients who have relapses after primary therapy is poor. Because of the rarity of primary mediastinal nonseminomatous germ cell tumors, there are few published data regarding salvage therapy for this disease. Conventional salvage chemotherapy does not induce durable, complete remission. In a recent report, it was shown that high-dose chemotherapy and autologous bone marrow support was not effective in the treatment of 12 patients with recurrent, refractory primary mediastinal nonseminomatous germ cell tumors. ${ }^{4}$

There is no information in the literature about salvage resection in patients with primary mediastinal nonseminomatous germ cell tumors. For the testicular counterparts of these tumors, it has recently been shown that in $50 \%$ of one patient population with chemorefractory but resectable germ cell tumors the disease can be cured by 
salvage resection. ${ }^{5}$ Our observation suggests that surgical resection of active tumor may cure patients with chemorefractory nonseminomatous mediastinal germ cell tumors. Serum levels of tumor marker reflect the histologic pattern of metastases, and cure is observed only for patients whose serum levels of tumor marker return to normal.

One major difficulty is precise identification of the location of active tumors in the patient to be operated on. Precise comparison of computed tomographic images may help to detect new nodules and to differentiate them from scars. Our observations, however demonstrate that all metastatic sites must be resected. Histologic examination of the removed tissue is not always conclusive, and both return to normal of serum levels of tumor marker and computed tomographic scan follow-up are needed to demonstrate completeness of surgical removal. Further experiences with salvage resection in cases of mediastinal germ cell tumors should be collected worldwide to demonstrate the value of this treatment.

\section{REFERENCES}

1. Davis RD, Oldham HN, Sabistan DC. Primary cysts and neoplasms of the mediastinum: recent changes in clinical presentation, methods of diagnosis, management and results. Ann Thorac Surg 1987;44:229-37.

2. Wright CD, Kesler KA, Nichols CR, Mahomed Y, Einhorn $\mathrm{LH}$, Miller ME, et al. Primary mediastinal nonseminomatous germ cell tumors: result of a multimodality approach. J Thorac Cardiovasc Surg 1990;99:210-7.

3. Nichols CR. Mediastinal germ cell-tumors: clinical features and biologic correlates. Chest 1991;99:472-9.

4. Broun ER, Nichols CR, Einhorn LH, Tricot GJ. Salvage therapy with high-dose chemotherapy and autologous bone marrow support in the treatment of primary nonseminomatous mediastinal germ cell tumors. Cancer 1991;68:1513-5.

5. Murphy BR, Breeden ES, Donohue JP, Messemer J, Walsh W, Roth BJ, et al. Surgical salvage of chemorefractory germ cell tumors. J Clin Oncol 1993;11:324-9. 